\title{
Left ventricular endocardial pacing for the critically ill
}

Citation for published version (APA):

Rinaldi, C. A., Auricchio, A., \& Prinzen, F. W. (2018). Left ventricular endocardial pacing for the critically ill. Intensive Care Medicine, 44(6), 915-917. https://doi.org/10.1007/s00134-018-5062-7

Document status and date:

Published: 01/06/2018

DOI:

10.1007/s00134-018-5062-7

Document Version:

Publisher's PDF, also known as Version of record

Document license:

Taverne

Please check the document version of this publication:

- A submitted manuscript is the version of the article upon submission and before peer-review. There can be important differences between the submitted version and the official published version of record.

People interested in the research are advised to contact the author for the final version of the publication, or visit the DOI to the publisher's website.

- The final author version and the galley proof are versions of the publication after peer review.

- The final published version features the final layout of the paper including the volume, issue and page numbers.

Link to publication

\footnotetext{
General rights rights.

- You may freely distribute the URL identifying the publication in the public portal. please follow below link for the End User Agreement:

www.umlib.nl/taverne-license

Take down policy

If you believe that this document breaches copyright please contact us at:

repository@maastrichtuniversity.nl

providing details and we will investigate your claim.
}

Copyright and moral rights for the publications made accessible in the public portal are retained by the authors and/or other copyright owners and it is a condition of accessing publications that users recognise and abide by the legal requirements associated with these

- Users may download and print one copy of any publication from the public portal for the purpose of private study or research.

- You may not further distribute the material or use it for any profit-making activity or commercial gain

If the publication is distributed under the terms of Article $25 \mathrm{fa}$ of the Dutch Copyright Act, indicated by the "Taverne" license above, 


\title{
Left ventricular endocardial pacing for the critically ill
}

\author{
C. A. Rinaldi $i^{*}$, A. Auricchio $^{3}$ and F. W. Prinzen ${ }^{2}$
}

(C) 2018 Springer-Verlag GmbH Germany, part of Springer Nature and ESICM

\section{Introduction}

Two decades ago cardiac resynchronization therapy (CRT) developed as a modality to reduce morbidity and mortality in patients with left ventricular (LV) dysfunction and a wide QRS complex (>120 ms) [1]. Twenty years earlier Gibson et al. had provided evidence of higher contractile force during biventricular as compared to right ventricular (RV) pacing in six patients on the critical care unit immediately after replacement of the aortic valve with a Starr-Edwards prosthesis [2].

\section{Haemodynamic effects and pathophysiological benefits of LV endocardial pacing}

Patients with a wide QRS complex, especially those with left bundle branch block (LBBB), and impaired LV pump function receive significant acute haemodynamic benefit with CRT using pacing at the RV endocardium and the LV epicardium via the coronary sinus [1]. Beneficial effects of CRT include increases in acute contractility (measured by $\mathrm{LV} \mathrm{d} P / \mathrm{d} t_{\text {max }}$ ), stroke work and cardiac output without the detrimental effect on myocardial oxygen demand seen with inotropes [3, 4]. Such effects may also be useful in critically ill patients. Evidence suggests that LV endocardial stimulation can provide a further improvement in acute haemodynamic response (AHR) over LV epicardial stimulation [5-7]. LV endocardial pacing may also provide access to optimal pacing sites in the LV. The superior AHR by LV endocardial pacing has been demonstrated in animal studies [5], computer modelling [6] and human studies [7]. Strik et al. found that in canine LBBB models LV endocardial stimulation increased LV $\mathrm{d} P / \mathrm{d} t_{\max }$ over conventional epicardial stimulation along

\footnotetext{
*Correspondence: c.rinaldi@virgin.net

${ }^{1}$ Cardiology Department, Guy's and St Thomas' NHS Trust, London SE1 7EH, UK

Full author information is available at the end of the article
}

with reduced electrical activation times as measured by contact mapping [5] (see Fig. 1). The exact mechanisms underlying the decreases in activation times for LV endocardial stimulation have not been fully elucidated but may include shorter activation path lengths for endocardial stimulation allowing earlier activation in remote regions and earlier activation of fast-conducting endocardial tissue, which has a higher conduction velocity $(\mathrm{CV})$ than epicardial tissue [5]. Computer modelling studies support this showing that LV endocardial stimulation creates a more physiological (i.e. from endocardium to epicardium) and more synchronous electrical activation resulting in superior LV contractility compared to epicardial CRT [6]. Human studies in patients with chronic heart failure have supported these experimental findings especially in patients with ischaemic heart disease where LV endocardial pacing may improve haemodynamics by avoiding pacing within LV scar and targeting areas of late electrical activation [7].

Currently, there are various possibilities to deliver LV endocardial pacing including the use of a bipolar transseptal lead [8], endocardial LV septal via bipolar lead [9], wirelessly [10] or using a deeply inserted temporary pacing wire at the time of cardiac surgery. A disadvantage of trans-septal LV endocardial CRT using a standard bipolar lead is that the currently available tools are limited, may alter mitral valve function and long-term anticoagulation is required. Therefore, clinical studies are limited to patients who either cannot receive standard CRT or who have not responded to it [8]. The industry-sponsored, non-controlled ALSYNC study also demonstrated that there are a non-negligible number of potential complications with chronic LV endocardial CRT, such as stroke, transient ischaemic attacks and major haemorrhage due to the need for effective anticoagulation [8]. However, application of LV endocardial CRT using trans-septal and transmitral lead placement is

\section{Springer}



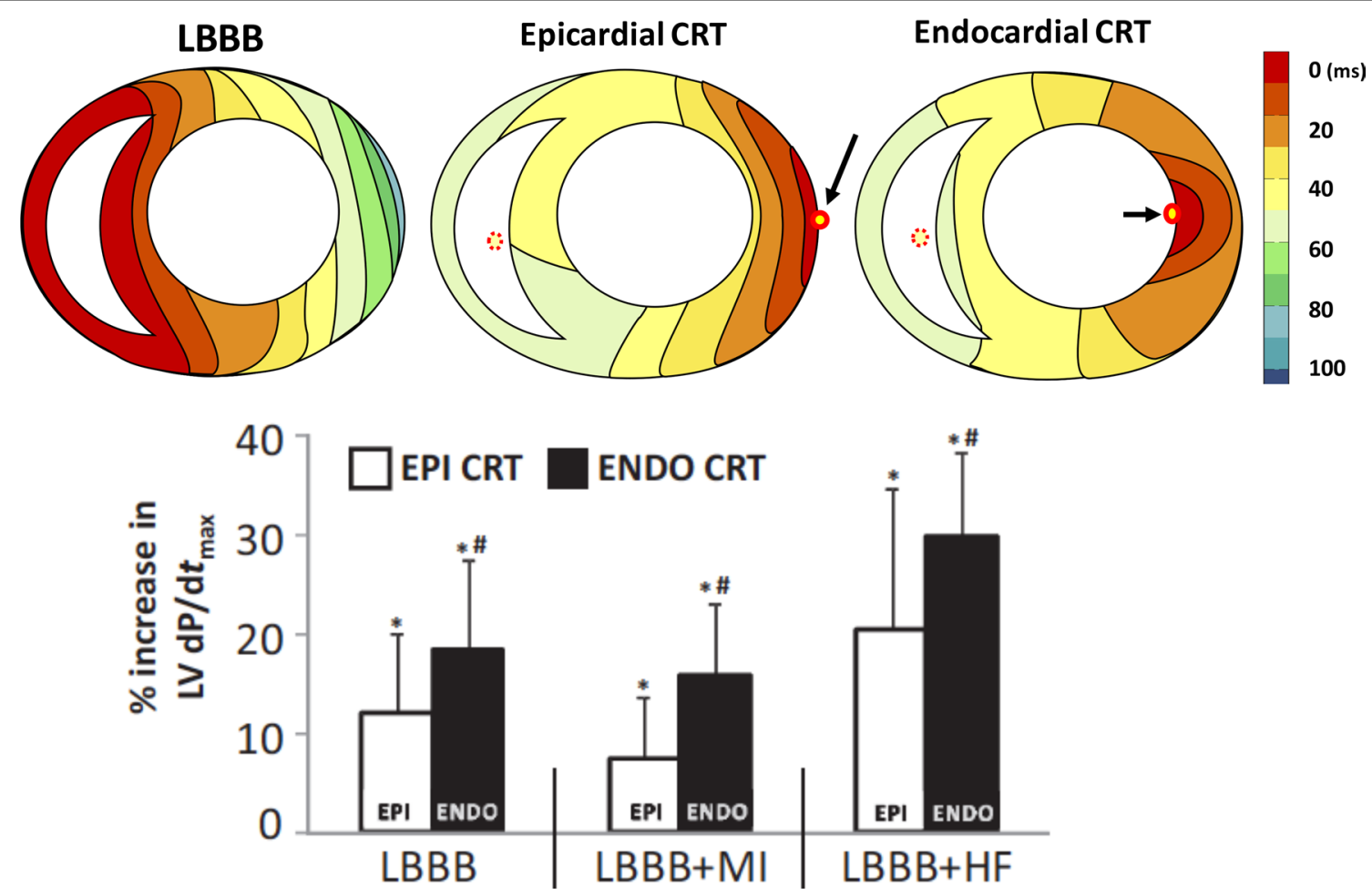

Fig. 1 Electrical activation during baseline LBBB, epicardial CRT and endocardial CRT, obtained by electrode band and multi-electrode array mapping in the dog model. Reproduced with permission from Ref. [5]. The red/orange circles denote the RV apical and LV pacing electrode. Lower panel shows changes in acute haemodynamic response with endocardial and epicardial pacing in the presence of LBBB alone, LBBB and infarction (MI) and LBBB and heart failure (HF). *Significantly different from baseline, "Significant from epicardial pacing

unpractical in the emergency setting as the technique is technically demanding, requiring long procedures involving fluoroscopy and the inherent risks and complications of left-sided catheterization [8]. Instead, patients undergoing open-heart surgery could be implanted with a temporary wire that is placed deeper in the LV wall (this would require redesign of the current temporary pacing technology). Finally, new tools for long-term use of LV endocardial pacing using a novel wireless technology for transmitting pacing energy only require a short period of oral antiplatelet therapy [10].

\section{Potential use of $L V$ endocardial stimulation in critically ill patients}

Several reasons to use pacing in the critically ill have been proposed. The first application of pacing is treatment of bradycardia, commonly using external pacemakers. The standard site of the ventricular electrode is the RV which like LBBB creates electrical and mechanical dyssynchrony that often worsen haemodynamics [11]. Secondly, biventricular pacing may be used to prevent ventricular desynchronization or to restore synchrony. The BLOCK-HF study demonstrated the benefit of biventricular pacing compared to RV pacing, with concurrent improvement of pump function and outcome in the chronic setting [12]. In keeping with this, BiV pacing can improve haemodynamics and reduce inotropic requirements in the setting of recovery from (open-heart) surgery [13]. This reduction in inotrope use may reduce myocardial oxygen demand [3] while resynchronization itself has also been shown to reduce myocardial oxygen consumption per unit of mechanical work [4]. Control of atrioventricular contraction interval by programming atrioventricular delay may also be important in patients with a prolonged PR interval, where ventricular filling may be improved. In the setting of chronic heart failure, biventricular pacing may be harmful when the QRS complex is narrow $(<120 \mathrm{~ms})$ [14]. However studies in the emergency setting show potential benefit with biventricular pacing in patients with a narrow QRS complex and mechanical intraventricular dyssynchrony [15]. Moreover in the porcine model acutely RV-overloaded hearts benefit from RV pre-excitation, whereas acute LV overload requires LV pre-excitation suggesting a further potential mechanism of benefit of biventricular pacing (with properly programmed AV and/ or VV intervals) by recruitment of the non-overloaded ventricle to support the overloaded one through mechanical interaction between the ventricles [16]. 
A relevant question is whether there are scenarios where LV endocardial pacing may be of additional benefit in critically ill patients. Currently the standard way to stimulate the LV is via a pacing lead either placed transvenously in a coronary vein or using a temporary epicardial wire post-surgery. Firstly, it must be emphasized that LV endocardial pacing in the setting of the critically ill patient is speculative, with very little data to support its use. As outlined above, it would make physiological sense to move from LV epicardial to LV endocardial pacing. Moreover, some of the problems that apply to the chronic patient may not be relevant in the emergency setting because patients are often already anticoagulated.

\section{Conclusion}

LV endocardial pacing is pathophysiologically plausible, but its feasibility and benefit in critically ill patients are yet to be proven. The complexity of current LV endocardial pacing lead implantation hampers application in the emergency setting. Post-surgical conditions, however, may offer the opportunity to implant newly designed LV endocardial leads that can subsequently be used for longer-term resynchronization. In any case the potential haemodynamic benefits of LV endocardial pacing have to be balanced against the potential for harm by delivering stimulation within the LV cavity.

\section{Author details \\ ${ }^{1}$ Cardiology Department, Guy's and St Thomas' NHS Trust, London SE1 7EH, UK. ${ }^{2}$ Department of Physiology, Cardiovascular Research Institute Maastricht, Maastricht, The Netherlands. ${ }^{3}$ Fondazione Cardiocentro Ticino, Lugano, Switzerland.}

\section{Compliance with ethical standards}

\section{Conflicts of interest}

CAR received research grants from Medtronic, St Jude Medical, LivaNova, Boston Scientific and EBR Systems. FWP received research grants from Medtronic, St Jude Medical, LivaNova, Biotronik, Sorin, Biosense Webster and EBR Systems. AA received speaker's fee from Medtronic, Boston Scientific, and LivaNova; he also received research grants from Medtronic, Biosense Webster and EBR

Received: 14 December 2017 Accepted: 11 January 2018

Published online: 19 January 2018

\section{References}

1. Cleland JGF, Daubert J-C, Erdmann E et al (2005) The effect of cardiac resynchronization on morbidity and mortality in heart failure. $N$ Engl $J$ Med 352:1539-1549
2. Gibson DG, Chamberlain DA, Coltart DJ, Mercer J (1971) Effect of changes in ventricular activation on cardiac haemodynamics in man. Comparison of right ventricular, left ventricular and simultaneous pacing of both ventricles. Br Heart J 33:397-400

3. Nelson GS, Berger RD, Fetics BJ, Talbot M, Spinelli JC, Hare JM, Kass DA (2000) Left ventricular or biventricular pacing improves cardiac function at diminished energy cost in patients with dilated cardiomyopathy and left bundle-branch block. Circulation 102(25):3053-3059

4. Kyriacou A, Pabari P, Mayet J et al (2014) Cardiac resynchronization therapy and AV optimization increase myocardial oxygen consumption, but increase cardiac function more than proportionally. Int J Cardiol 171:144-152

5. Strik M, Rademakers LM, van Deursen CJ, van Hunnik A, Kuiper M, Klersy C, Auricchio A, Prinzen FW (2012) Endocardial left ventricular pacing improves cardiac resynchronization therapy in chronic asynchronous infarction and heart failure models. Circ Arrhythm Electrophysiol 5(1):191-200

6. Hyde ER, Behar JM, Claridge S et al (2015) Beneficial effect on cardiac resynchronization from left ventricular endocardial pacing is mediated by early access to high conduction velocity tissue: electrophysiological simulation study. Circ Arrhythmia Electrophysiol 8:1 164-1172

7. Behar JM, Jackson T, Hyde E et al (2016) Optimized left ventricular endocardial stimulation is superior to optimized epicardial stimulation in ischemic patients with poor response to cardiac resynchronization therapy a combined magnetic resonance imaging, electroanatomic contact mapping and hemodynamic study to target endocardial lead placement. JACC Clin Electrophysiol 2(7):799-809

8. Morgan JM, Biffi M, Geller L et al (2016) Alternate Site Cardiac Res YNChronization (ALSYNC): a prospective and multicentre study of left ventricular endocardial pacing for cardiac resynchronization therapy. Eur Heart J 37:2118-2127

9. Mafi-Rad M, Luermans JG, Blaauw Y, Janssen M, Crijns HJ, Prinzen FW, Vernooy K (2016) Feasibility and acute hemodynamic effect of left ventricular septal pacing by transvenous approach through the interventricular septum. Circ Arrhythm Electrophysiol. 9(3):e003344

10. Auricchio A, Delnoy PP, Butter C et al (2014) Feasibility, safety, and shortterm outcome of leadless ultrasound-based endocardial left ventricular resynchronization in heart failure patients: results of the wireless stimulation endocardially for CRT (WiSE-CRT) study. Europace 16:681-688

11. Tse HF, Yu C, Wong KK, Tsang V, Leung YL, Ho WY, Lau CP (2002) Functional abnormalities in patients with permanent right ventricular pacing: the effect of sites of electrical stimulation. J Am Coll Cardiol 40:1451-1458

12. Curtis AB, Worley S, Adamson PB, Chung E, Niazi I, Sherfesee L, Shinn T, Sutton MS (2013) Biventricular pacing for atrioventricular block and systolic dysfunction. New Engl J Med 368:1585-1593

13. Weisse U, Isgro F, Werling C, Lehmann A, Saggau W (2002) Impact of atriobiventricular pacing to poor left-ventricular function after CABG. Thorac Cardiovasc Surg 50(3):131-135

14. Ruschitzka F, Abraham WT, Singh JP et al (2013) Cardiac-resynchronization therapy in heart failure with a narrow QRS complex. New Engl J Med 369(15):1395-1405

15. Mullens W, Borowski AG, Curtin R, Grimm RA, Thomas JD, Tang WH (2008) Mechanical dyssynchrony in advanced decompensated heart failure: relation to hemodynamic responses to intensive medical therapy. Heart Rhythm. 5(8):1105-1110

16. Rabkin D, Cabreriza E, Curtis L et al (2004) Load dependence of cardiac output in biventricular pacing: right ventricular pressure overload in pigs. J Thorac Cardiovasc Surg 127(6):1713-1722 